\title{
The Detection of STAT1 Gene Influencing Milk Related Traits in Turkish Holstein and Jersey Cows
}

\author{
Ozden Cobanoglu ${ }^{1}$, Eser Kemal Gurcan ${ }^{2}$, Soner Cankaya ${ }^{3}$, Ertugrul Kul ${ }^{4}$ and Hasan Samet Abaci $^{5}$ \\ 1. Department of Genetics, Faculty of Veterinary Medicine, Uludag University, Bursa 16059, Turkey \\ 2. Department of Animal Science, Faculty of Agriculture, Namik Kemal University, Tekirdag 59030, Turkey \\ 3. Department of Biostatistics, Faculty of Medicine, Ordu University, Ordu 52200, Turkey \\ 4. Department of Animal Science, Faculty of Agriculture, Ahi Evran University, Kirsehir 40200, Turkey \\ 5. Department of Animal Science, Faculty of Agriculture, Ondokuz Mayis University, Samsun 55100, Turkey
}

\begin{abstract}
The main purpose of this study was to detect an association of cytoplasmic signal transducers and activators of transcription-1 (STAT1) with milk production traits in 472 Holstein and 283 Jersey cattle breeds of Turkey. This gene, located on chromosome 2, was chosen due to its role on development of mammary gland. A polymorphism of selected 314 bp allele fragment was detected by the restriction fragment length polymorphism analysis of polymerase chain reaction-amplified fragments (PCR-RFLP) method and also confirmed by DNA sequencing. The association tests were conducted between STAT1 genotypes and some economically important dairy traits. The genotypes for $C / T$ as a single nucleotide polymorphism (SNP) were identified at interval $60 \mathrm{cM}$ to $63 \mathrm{cM}$. The effects of STAT1 gene on milk production traits were not significant in Holstein cows, although animals with $C T$ genotypes showed fairly close to significant value for the corrected $305 \mathrm{~d}$ milk yield. However, Jersey cows with $T T$ genotype were $2.07 \mathrm{~kg}$ higher for test-day milk yield $(P<0.05), 0.13 \mathrm{~kg}$ for fat yield $(P<0.01)$ and $0.07 \mathrm{~kg}$ for protein yield $(P<$ 0.05) compared with animals having CC and CT genotypes. Definitely, the further research should be conducted to search this gene intensively with larger samples to identify polymorphism and any association between the economically important traits and genotypic class in Holstein cows. Finally, based on the findings, it was concluded that STAT1 gene might be used as a potential candidate gene to improve milk yield and milk fat and protein contents in dairy cows breeding programs.
\end{abstract}

Key words: STAT1 gene, dairy cattle, PCR-RFLP, milk production, milk content.

\section{Introduction}

There are many genes that have a major effect on the economically important traits in dairy cattle. One of the major genes reported to have an influence on these types of traits is cytoplasmic signal transducers and activators of transcription factors (STAT). This is an actually big gene family, which is known as seven different forms (STAT1, STAT2, STAT3, STAT4, STAT5A, STAT5B and STAT6) based on the function and structure so far. This group of genes is to be a member of latent cytoplasmic transcription factors [1]. The STAT protein as the part of transcription factors has a major role in cytokine signaling pathways and is

Corresponding author: Ozden Cobanoglu, Ph.D., research field: animal genetics and breeding. activated through a cascade of phosphorylation events, where janus tyrosine kinases (JAKs) are activated firstly and then cause STATs to be phosphorylated at their tyrosine residues [2]. Therefore, STATs with JAKs play a distinct role for plenty of polypeptide hormones and cytokinesis to display their biological functions [3].

Actually, a single extracellular signal activates STAT2, STAT4 and STAT6 within this family. This group of genes is critical for interferon (IFN) receptor signaling and development of T-cells. However, a large number of extra and intra cellular factors cause for activating STAT1, STAT3, STAT5A and STAT5B genes, which are also included in IFN signaling, embryogenesis and mammary gland development process [4]. 
All of these various forms of bovine STAT genes have been detected and mapped in different chromosomes. As a candidate one, STAT1 gene is located on the chromosome 2 between $60 \mathrm{cM}$ and 63 cM interval [5]. STAT1 is regulated during mammary gland development and since it is constitutively active, it plays an important role on a development as well as a differentiation of the mammary gland as an oncogene. The other study also displayed that STAT1 was highly related with fertility and early embryonic survival rates, which could be taken into account for dairy cattle inbreeding program to improve animal prolificacy [6]. Moreover, some of the earlier studies showed that a single-nucleotide polymorphism (SNP) marker located on 3'-untranslated region (3'UTR) at the position 3,141 bp in STAT1 is significantly related with milk protein percentage [7] and milk fat yield and milk fat percentage [8].

There are many studies completed to determine just the polymorphism at some of the important genes in various cow, goat and sheep, even water buffalo breeds throughout the country. However, there was not any comprehensive study so far conducted to do an association test between the economically important traits, like milk production traits and the putative candidate genes affecting the production level of livestock species in Turkey based on genotypic evaluation of animals, which will have collected phenotypic data about the traits of interest. Therefore, the main goal of this study was to investigate an association of STAT1 gene polymorphism with milk yield and milk component traits in two major dairy cattle breeds raised in Turkey.

\section{Materials and Methods}

\subsection{Animal Sources and Phenotypic Information}

The study involved a total of 755 dairy cows, which were 309 Holstein raised in west (Marmara region), and 163 Holstein and 283 Jersey raised in north part of country (Black Sea region). Jersey is adapted and raised mostly in Black Sea region due to an optimal environmental condition for this dairy breed. Data on daily milk production records (test-day records) were obtained monthly basis during the lactation periods for three years. Milk fat and protein contents were determined within $12 \mathrm{~h}$ by ultrasonic milk analyzer from milk samples collected from lactating animals during monthly milk test days (MilkoScan ${ }^{\mathrm{TM}}$ FT1, Foss, Hillerod, Denmark). Also, milk protein yield and milk fat yield were calculated based on the milk production levels obtained from the analysis, as Eqs. (1) and (2):

Milk protein yield $=$ milk yield on the test day

$\times$ protein content

Milk fat yield $=$ milk yield on the test day

$\times$ fat content

\subsection{DNA Extraction, Genotyping and Sequencing}

Blood samples were collected from total of 755 cows. The collection of $10 \mathrm{~mL}$ samples from the jugular vein into vacuum tubes coated with $\mathrm{K}_{2}$ EDTA anticoagulant was performed using standard phenol/chloroform method [9]. The quality and quantity of DNA samples were evaluated using NanoDrop Spectrophotometer (Thermo Fisher Scientific Inc., USA) and electrophoresis techniques. Polymerase chain reaction-amplified fragments (PCR-RFLP) method was used to detect SNP in STAT1 gene (accession number: AW289395). The amplification of genomic DNA was carried out with a total volume of $25 \mu \mathrm{L}$ in PCR reaction, including 50 ng of genomic DNA, $50 \mu \mathrm{M}$ of each primer, $200 \mu \mathrm{M}$ each dNTP, $2.5 \mu \mathrm{L}$ of $10 \times$ PCR buffer and $0.3 \mathrm{U}$ of Taq polymerase (Thermo Fisher Scientific Inc., USA). Primer sequences used for $314 \mathrm{bp}$ fragment containing a polymorphic BspHI restriction enzyme site were 5-GCCTCAAGTTTGCCAGTGGC-3' and 5'-GGCTCCCTTGATAGAACTGT-3' at 3'UTR [10]. The amplification program was $95{ }^{\circ} \mathrm{C}$ for $5 \mathrm{~min}, 32$ cycles of $94{ }^{\circ} \mathrm{C}$ for $45 \mathrm{~s}$, touchdown annealing from $62{ }^{\circ} \mathrm{C}$ to $50{ }^{\circ} \mathrm{C}$ for $45 \mathrm{~s}\left(-2{ }^{\circ} \mathrm{C} /\right.$ cycle $), 72{ }^{\circ} \mathrm{C}$ for $45 \mathrm{~s}$, and a final extension of $72{ }^{\circ} \mathrm{C}$ for $10 \mathrm{~min} .10 \mu \mathrm{L}$ of 
PCR product was digested with $10 \mathrm{U} / \mu \mathrm{L} \quad B s p H I$ enzyme (Thermo Fisher Scientific Inc., USA) at $37{ }^{\circ} \mathrm{C}$ for about $4 \mathrm{~h}$ to determine $C / T$ allelic polymorphism. Also DNA sequence analysis was performed to confirm the accuracy of genotyping related to the SNP region of STAT1. The confirmation of the genotyping was checked by performing double-sided DNA sequencing, both forward and reverse, for a sufficient number of samples representing all cows used in the research.

\subsection{Statistical Analysis}

The chi-square test $\left(\chi^{2}\right)$ was used to check whether the distribution of the frequencies was in Hardy-Weinberg equilibrium. Furthermore, an association test was conducted between STAT1/BspHI genotypes and the milk production traits using the least square analysis in SPSS 13.00 software package [11]. The animals in the study were grouped according to lactation period (1st, 2nd, 3rd, 4th, 5th and more), and the mean, standard error, minimum and maximum values are calculated for the $305 \mathrm{~d}$ milk yield (305 DMY), test day milk yield (TDMY), fat percentage (\%), fat yield, protein percentage (\%) and protein yield in milk based on the genotypic class of STAT1 gene, separately. The comparison of the differences among the genotypic groups affecting milk yield and milk component traits was made according to the Duncan multiple comparison test. The statistical model used for this purpose is expressed below. Since the lactation period was corrected for the calculating $305 \mathrm{~d}$ milk yield, the factor of $b\left(E_{m}\right)$ was removed from the model to analyze the effect of genotype on this trait, as Eq. (3):

$$
Y_{i j k l m n}=\mu+A_{i}+B_{j}+C_{k}+D_{l}+b\left(E_{m}\right)+\mathcal{E}_{i j k l m n} \text { (3) }
$$

where, $Y_{i j k l m n}$ - the observation values, like TDMY $(\mathrm{kg} / \mathrm{d}), 305 \mathrm{~d}$ milk yield $(\mathrm{kg})$, and milk component traits;

$\mu$-overall mean for investigated herd;

$A_{i}$ - the ith genotypic effect;

$B_{j}$ - the $j$ th calving season;
$C_{k}$-the $k$ th month of calving;

$D_{l}$ - the lth lactation period;

$E_{m}$ - the $m$ th lactation length for the $n$th cow;

$b$-regression coefficient for lactation length given milk related traits;

$\mathcal{E}_{i j k l m n}$-random residual effect.

\section{Results and Discussion}

The $C$ and $T$ alleles of the STAT1 gene were identified based on the amplification of a $314 \mathrm{bp}$ fragment, followed by digestion reaction with a restriction enzyme of BspH1 (Fig. 1a). All genotypes were precisely scored based on banding pattern at gel electrophoresis. DNA fragments were identified as intact $314 \mathrm{bp}$ for TT, fragments of 314, 201 and 113 bp for $C T$, and $201 \mathrm{bp}$ and $113 \mathrm{bp}$ for CC genotypes. Also genotyping reaction was confirmed by DNA sequencing reaction with sufficient amount of sample representing the entire population. A part of DNA sequence with polymorphic site with $C C, C T$ and $T T$ genotypes was shown in Figs. 1b, $1 \mathrm{c}$ and $1 \mathrm{~d}$, respectively.

PCR-RFLP results revealed that there are three different patterns of DNA fragments existing for STAT1 gene. Different genotypic assignments based on DNA banding pattern in gel electrophoresis were also confirmed by DNA sequence analysis for STAT1/BspH1 polymorphism (Fig. 1). Result of chi-square test indicated that while the Holstein cows were detected under a Hardy-Weinberg equilibrium, Jersey did not follow the equilibrium more likely due to the breeder selection criteria for milk production. The mean, standard deviation, minimum and maximum values about TDMY $(\mathrm{kg} / \mathrm{d}), 305 \mathrm{~d}$ milk yield $(\mathrm{kg})$, milk fat percentage (\%), fat yield $(\mathrm{kg} / \mathrm{d})$, protein percentage $(\%)$ and protein yield $(\mathrm{kg} / \mathrm{d})$ for different genotypes of STAT1 gene were given based on lactation period, calving season and the month of calving for Jersey breed raised in Black Sea region of Turkey in Table 1. Three different genotypes of STAT1 gene (CC, CT and TT) were segregating 
among Jersey cows. There was a statistically significant difference observed among these genotypic groups of animals in a herd. Based on the statistical analysis, there were significant differences for TDMY $(P=$ $0.021)$, test day fat yield $(P=0.008)$ and protein yield $(P=0.028)$ among Jersey cows based on the genotypic groups, while there were not important differences in terms of any other traits (Table 1). Jersey cows carrying TT genotype for TDMY, fat and protein yields had the highest, while the animals carrying the $C C$ genotype displayed the lowest values for the same traits.

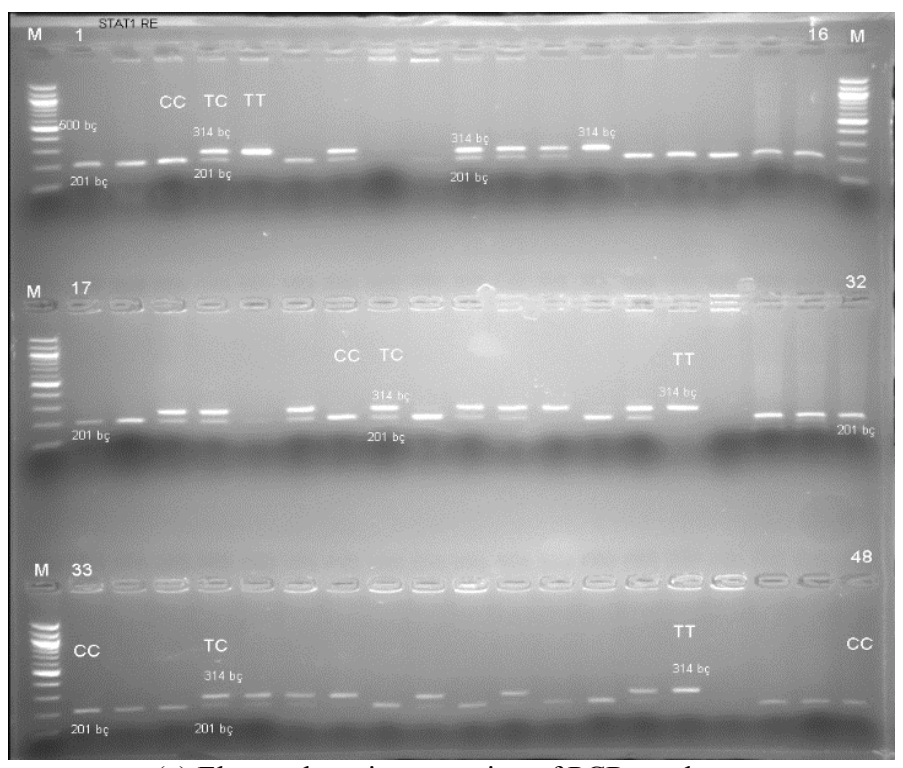

(a) Electrophoretic separation of PCR products

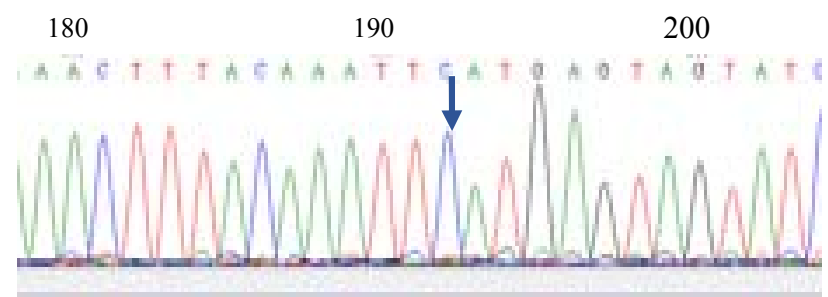

(b) CC genotype

180

200

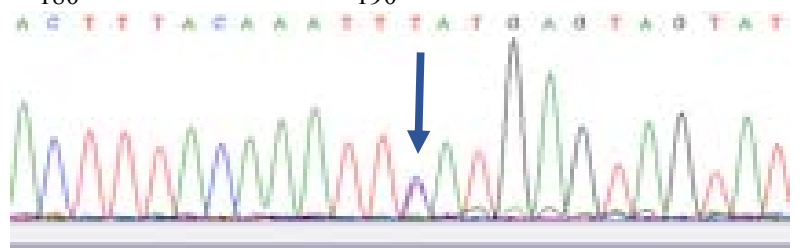

(c) CT genotype

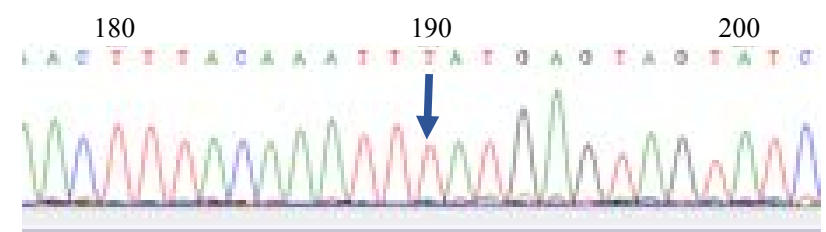

(d) TT genotype

Fig. 1 Electrophoretic separation of PCR products digested with BspH1 and DNA sequence analysis for CC, CT and TT genotypes for STAT1 gene in Holstein cows. 
Turkish Holstein and Jersey Cows

Table 1 Effects of STAT1/BspHI polymorphism on milk production traits for Jersey cows raised in Black Sea region of Turkey.

\begin{tabular}{|c|c|c|c|c|c|c|c|}
\hline \multirow{2}{*}{ Genotype } & \multirow{2}{*}{ Value } & \multicolumn{6}{|c|}{ Milk production traits } \\
\hline & & TDMY (kg/d) & 305 DMY (kg) & Fat (\%) & Fat yield $^{*}(\mathrm{~kg} / \mathrm{d})$ & Protein $(\%)$ & Protein yield ${ }^{*}(\mathrm{~kg} / \mathrm{d})$ \\
\hline \multirow{5}{*}{$C C$} & $n$ & 123 & 123 & 123 & 123 & 123 & 123 \\
\hline & $\bar{X}$ & $15.33^{\mathrm{b}}$ & $4,995.5$ & 4.97 & $0.76^{\mathrm{b}}$ & 3.40 & $0.52^{\mathrm{b}}$ \\
\hline & $\mathrm{SD}$ & 3.29 & $1,261.2$ & 0.58 & 0.16 & 0.15 & 0.11 \\
\hline & Min & 3.74 & $1,480.0$ & 3.41 & 0.18 & 2.94 & 0.13 \\
\hline & Max & 22.10 & $8,895.0$ & 6.72 & 1.14 & 3.87 & 0.76 \\
\hline \multirow{5}{*}{$C T$} & $n$ & 149 & 149 & 149 & 149 & 149 & 149 \\
\hline & $\bar{X}$ & $16.11^{\mathrm{ab}}$ & $5,178.4$ & 5.02 & $0.80^{\mathrm{b}}$ & 3.37 & $0.54^{\mathrm{ab}}$ \\
\hline & $\mathrm{SD}$ & 3.20 & $1,477.1$ & 0.66 & 0.16 & 0.17 & 0.10 \\
\hline & Min & 6.60 & $2,126.0$ & 3.94 & 0.28 & 2.91 & 0.21 \\
\hline & Max & 23.47 & $1,1874.0$ & 7.48 & 1.25 & 3.95 & 0.78 \\
\hline \multirow{5}{*}{ TT } & $n$ & 11 & 11 & 11 & 11 & 11 & 11 \\
\hline & $\bar{X}$ & $17.40^{\mathrm{a}}$ & $5,325.0$ & 5.19 & $0.89^{\mathrm{a}}$ & 3.42 & $0.59^{\mathrm{a}}$ \\
\hline & SD & 3.13 & 975.4 & 0.71 & 0.08 & 0.28 & 0.08 \\
\hline & Min & 11.63 & $3,778.0$ & 4.38 & 0.78 & 3.12 & 0.47 \\
\hline & Max & 22.37 & $7,006.0$ & 6.70 & 1.04 & 4.03 & 0.70 \\
\hline \multicolumn{2}{|l|}{$P$ value } & 0.021 & 0.305 & 0.605 & 0.008 & 0.531 & 0.028 \\
\hline \multicolumn{2}{|l|}{$b$} & $\begin{array}{l}0.006 \\
(0.016)\end{array}$ & $\begin{array}{l}- \\
-\end{array}$ & $\begin{array}{l}0.001 \\
(0.028)\end{array}$ & $\begin{array}{l}<0.001 \\
(0.341) \\
\end{array}$ & $\begin{array}{l}<0.001 \\
(0.030)\end{array}$ & $\begin{array}{l}<0.001 \\
(0.059) \\
\end{array}$ \\
\hline
\end{tabular}

TDMY: test day milk yield; 305 DMY: 305 d milk yield; SD: standard deviation.

$b$ : regression coefficient for lactation length and the values given in brackets indicates the level of importance for the $b$ values.

${ }^{*}$ Fat and protein yields $(\mathrm{kg})$ were calculated based on TDMY.

${ }^{\mathrm{a}, \mathrm{b}}$ The differences between the group means with different letters in the same column are significant $(P<0.05)$.

The values for the same milk related traits based on the genotypes for STAT1 were given for Holstein cows raised in Black Sea region in Table 2 and Marmara region in Table 3. Interestingly, there were not any significant differences among the genotypic groups of Holstein cows for the milk traits, although the major differences were observed among genotypes for $305 \mathrm{~d}$ milk yield $(P=0.063)$. Yet, animals with $C T$ genotypes showed higher values for all the traits than those with the other genotypes. Moreover, there were not any important differences among Holstein cows with three different genotypes of STAT1 raised in west part of country for the milk yield traits as well. Unlike, the Holstein cows in north side of Turkey, animals carrying CC genotypes displayed a higher amount of $305 \mathrm{~d}$ milk yield in west part.

There were not many studies investigating the association between the genotypic effect and the economically important traits in livestock populations in Turkey, due to lack of enough phenotypic records from genotyped animals or having animals with genotype but no records kept for such important traits. Thus, this research might be accepted as one of the important research, which needs to be done in nationwide to deal with shortages in this area. Due to the lack of sufficient number of records for the traits of interest, a study to determine just polymorphism or actually a genetic variant generated by the mutation does not make much of sense. It has to be statistically tested to reveal the effect of gene on any trait of interest.

Indeed, there is not much of study searching the effect of STAT1 on milk yield and milk composition traits in literatures, either. There have been many quantitative trait loci (QTL) studies looking for the relationship between molecular markers, especially 
Table 2 Effects of STAT1/BspHI polymorphism on milk production traits for Turkish Holstein cows raised in Black Sea region.

\begin{tabular}{|c|c|c|c|c|c|c|c|}
\hline \multirow{2}{*}{ Genotype } & \multirow{2}{*}{ Value } & \multicolumn{6}{|c|}{ Milk production traits } \\
\hline & & TDMY (kg/d) & 305 DMY (kg) & Fat $(\%)$ & Fat yield ${ }^{*}(\mathrm{~kg} / \mathrm{d})$ & Protein $(\%)$ & Protein yield ${ }^{*}(\mathrm{~kg} / \mathrm{d})$ \\
\hline \multirow{5}{*}{$C C$} & $n$ & 89 & 89 & 89 & 89 & 89 & 89 \\
\hline & $\bar{X}$ & 18.84 & $6,501.9$ & 4.20 & 0.79 & 3.24 & 0.61 \\
\hline & SD & 4.49 & $1,566.8$ & 0.59 & 0.20 & 0.17 & 0.13 \\
\hline & Min & 9.37 & $2,960.0$ & 2.59 & 0.30 & 2.85 & 0.32 \\
\hline & Max & 31.06 & $11,143.0$ & 5.58 & 1.26 & 3.68 & 0.92 \\
\hline \multirow{5}{*}{$C T$} & $n$ & 64 & 64 & 64 & 64 & 64 & 64 \\
\hline & $\bar{X}$ & 20.51 & $7,175.2$ & 4.03 & 0.82 & 3.23 & 0.66 \\
\hline & SD & 3.75 & $1,811.0$ & 0.48 & 0.15 & 0.16 & 0.11 \\
\hline & Min & 11.65 & $3,160.0$ & 3.21 & 0.53 & 2.93 & 0.38 \\
\hline & Max & 27.50 & $13,887.0$ & 5.42 & 1.13 & 3.90 & 0.83 \\
\hline \multirow{5}{*}{$T T$} & $n$ & 10 & 10 & 10 & 10 & 10 & 10 \\
\hline & $\bar{X}$ & 19.54 & $6,148.3$ & 4.01 & 0.78 & 3.21 & 0.62 \\
\hline & SD & 4.50 & $1,263.9$ & 0.41 & 0.16 & 0.17 & 0.12 \\
\hline & Min & 13.47 & $3,804.0$ & 3.47 & 0.54 & 2.96 & 0.47 \\
\hline & Max & 27.40 & $7,905.0$ & 4.65 & 1.02 & 3.50 & 0.81 \\
\hline \multicolumn{2}{|l|}{$P$ value } & 0.187 & 0.063 & 0.148 & 0.764 & 0.776 & 0.138 \\
\hline \multicolumn{2}{|l|}{$b$} & $\begin{array}{l}0.004 \\
(0.157)\end{array}$ & $\begin{array}{l}- \\
-\end{array}$ & $\begin{array}{l}0.001 \\
(0.145)\end{array}$ & $\begin{array}{l}<0.001 \\
(0.549)\end{array}$ & $\begin{array}{l}<0.001 \\
(0.378)\end{array}$ & $\begin{array}{r}<0.001 \\
(0.086)\end{array}$ \\
\hline
\end{tabular}

TDMY: test day milk yield; 305 DMY: 305 d milk yield; SD: standard deviation.

$b$ : regression coefficient for lactation length and the values given in brackets indicates the level of importance for the $b$ values.

${ }^{*}$ Fat and protein yields $(\mathrm{kg})$ were calculated based on TDMY.

Table 3 Effects of STAT1/BspHI polymorphism on milk production traits for Turkish Holstein cows raised in Marmara region of Turkey.

\begin{tabular}{|c|c|c|c|c|c|c|c|}
\hline \multirow{2}{*}{ Genotype } & \multirow{2}{*}{ Value } & \multicolumn{6}{|c|}{ Milk production traits } \\
\hline & & TDMY (kg/d) & 305 DMY (kg) & Fat $(\%)$ & Fat yield* $(\mathrm{kg} / \mathrm{d})$ & Protein $(\%)$ & Protein yield $^{*}(\mathrm{~kg} / \mathrm{d})$ \\
\hline \multirow{5}{*}{$C C$} & $n$ & 140 & 140 & 140 & 140 & 140 & 140 \\
\hline & $\bar{X}$ & 26.53 & $9,134.1$ & 3.67 & 0.96 & 3.13 & 0.82 \\
\hline & SD & 6.00 & $2,158.2$ & 0.60 & 0.22 & 0.28 & 0.17 \\
\hline & Min & 11.87 & $3,659.0$ & 2.04 & 0.39 & 2.40 & 0.38 \\
\hline & Max & 41.13 & $15,809.0$ & 5.63 & 1.61 & 3.79 & 1.26 \\
\hline \multirow{5}{*}{$C T$} & $n$ & 127 & 127 & 127 & 127 & 127 & 127 \\
\hline & $\bar{X}$ & 26.49 & $8,743.8$ & 3.68 & 0.96 & 3.18 & 0.83 \\
\hline & SD & 5.99 & $2,033.9$ & 0.59 & 0.22 & 0.31 & 0.17 \\
\hline & Min & 11.19 & $3,179.0$ & 2.45 & 0.42 & 2.53 & 0.38 \\
\hline & Max & 43.00 & $13,982.0$ & 5.89 & 1.65 & 4.08 & 1.35 \\
\hline \multirow{5}{*}{$T T$} & $n$ & 42 & 42 & 42 & 42 & 42 & 42 \\
\hline & $\bar{X}$ & 26.12 & $8,807.6$ & 3.63 & 0.94 & 3.19 & 0.83 \\
\hline & SD & 5.55 & $2,057.4$ & 0.56 & 0.21 & 0.31 & 0.18 \\
\hline & Min & 12.23 & $4,356.0$ & 2.87 & 0.36 & 2.59 & 0.37 \\
\hline & Max & 36.38 & $12,624.0$ & 4.85 & 1.52 & 3.82 & 1.21 \\
\hline \multicolumn{2}{|l|}{$P$ value } & 0.800 & 0.301 & 0.957 & 0.804 & 0.309 & 0.829 \\
\hline \multicolumn{2}{|l|}{$b$} & $\begin{array}{l}0.004 \\
(0.222)\end{array}$ & $\begin{array}{l}- \\
-\end{array}$ & $\begin{array}{l}<0.001 \\
(0.595)\end{array}$ & $\begin{array}{l}<0.001 \\
(0.364)\end{array}$ & $\begin{array}{l}<0.001 \\
(0.515)\end{array}$ & $\begin{array}{l}<0.001 \\
(0.091)\end{array}$ \\
\hline
\end{tabular}

TDMY: test day milk yield; 305 DMY: 305 d milk yield; SD: standard deviation.

$b$ : regression coefficient for lactation length and the values given in brackets indicates the level of importance for the $b$ values.

${ }^{*}$ Fat and protein yields $(\mathrm{kg})$ were calculated based on TDMY. 
microsatellites and milk production traits through the whole genome scan which were including markers close to the STAT1 location [7, 8]. Mao et al. [12] reported that STATs family may be influencing the synthesis of protein and regulating fat metabolism in mammary gland due to prolactin signaling activities of the STATs. Specifically, the first study was conducted to determine the effect of STAT1 as a functional candidate gene on milk production traits using two big and elite US Holstein populations in 2006 [10]. They reported a significant association between SNP $(C / T)$ polymorphism on 3'UTR of STAT1 and milk production traits in Holstein dairy cattle and observed that genotypes CC and CT were highly associated with milk yield, milk fat and protein yields in the University of Wisconsin population. Also, an allele $C$ had significant effect on milk fat and protein percentages in the repository population. Even if Turkish Holstein cows raised in the Marmara and Black Sea regions have not displayed a significant influence on milk yield and component traits for the STAT1 gene, animals carrying $C T$ genotypes had higher values for all the milk related traits in this study, which is kind of an agreement with the study conducted with US Holstein cows. The effect of STAT1 gene on TDMY, test day fat and protein yields in Jersey cows was also found to be statistically significant in the current study. However, as a matter of fact, Jersey cattle carrying TT genotype were higher for TDMY (2.07 $\mathrm{kg})$, fat yield $(0.13 \mathrm{~kg})$ and protein yield $(0.07 \mathrm{~kg})$ than cows with $C C$ and $C T$ genotypes in contrast to Holstein cows. In a subsequent polymerase chain reaction-single strand conformation polymorphism (PCR-SSCP) study with Chinese Holstein cows, it was confirmed that animals carrying $C C$ or $C T$ genotypes had highly associated with $305 \mathrm{~d}$ milk yield in the first and second calving, and animals having CC genotype had significantly related with protein percentage than animals carrying $T T$ genotype in the first and third calving [13]. Conversely, a relatively high association between STAT1/Pag1 polymorphism and milk fat percentage was reported in Esfahan Holstein breed, and cows with $D D$ genotype had higher production level among the seven genotypic groups [14]. On the other hand, a study conducted with Czech Fleckvieh cows showed that there were statistically significant differences between animals with CC and animals with $C T$ genotypes in terms of estimated breeding values for protein and fat percentages. However, it was also reported that even if cows with $C T$ genotype had a higher protein percentage than cows with the other genotypes, the genotypic effect on the milk content related trait was not significant [15]. The observed discrepancy between genotypic effects of the same gene from study to study could be due to the usage of different breeds in various studies, as well as utilization of selected cows which have assorted genetic backgrounds to carry out breeding strategies with different goals. As a matter of fact, a high association of allele $C$ with milk yield and the production of milk content traits was also confirmed in the present study.

There are also some conducted studies related with this gene which has an influence on production traits in water buffalo breeds recently. One of the studies was conducted with river type buffalo breeds to detect the polymorphism in the same 3'UTR region of STAT1 gene, but interestingly there was no genetic variation observed at this loci due to monomorphic patterns of the gene in these breeds. They assumed that in contrast to dairy breeds, an allele could be fixed at that position. Based on these findings, a genetic composition of water buffaloes might differ from cattle breeds and that is why they could not detect any association in that region [16]. On the contrary, in a quite new study, 18 SNP were detected on STAT1 gene using Chinese crossbred buffaloes [17] and it was reported that some of the SNP was highly 
associated with $305 \mathrm{~d}$ milk yield and milk component, but any significant association between the SNP at 3'UTR region and milk production traits was not revealed, either. Therefore, it would be better to extent the study of associated alleles in different region in the same gene or the completely different genes for production traits in terms of water buffalo breeds.

\section{Conclusions}

In this study, the effect of selected SNP allele in STAT1 gene on milk yields and milk composition related traits was reported in dairy breeds, especially in Jersey population. Based on the findings, there are strong associations between TT genotype and TDMY, milk fat and protein yields. An allele $C$ has a tendency to associate with milk related traits in dairy cattle breeds. As a conclusion, the present results suggest that STAT1 gene might be used as a potential candidate gene, and the detected SNP markers should be considered and taken into account for selecting dairy cows to improve milk production. But, a further study will also be needed to clarify if there is an association between milk production traits and SNP regions with large enough samples representing Turkish Holstein population.

\section{Acknowledgments}

The study had an approval from the Ethical Committee of Namik Kemal University, Turkey and was supported by the Scientific and Technological Research Council of Turkey (TUBITAK) with project number \#110 O 821.

\section{References}

[1] Darnell, J. E. 1997. "STATs and Gene Regulation." Science 277 (5332): 1630-5.

[2] Kisseleva, T., Bhattacharya, S., Braunstein, J., and Schindler, C. W. 2002. "Signaling through the JAK/STAT Pathway, Recent Advances and Future Challenges." Gene. 285 (1-2): 1-24.

[3] Ihle, J. N. 1995. "Cytokine Receptor Signalling." Nature 377 (6550): 591-4.

[4] Darnell, J. E. 1996. "Reflections on STAT3, STAT5 and
STAT6 as Fat STATs." Proc. Natl. Acad. Sci. USA 93 (13): 6221-4.

[5] Band, M. R., Larson, J. H., Rebeiz, M., Green, C. A., Heyen, D. W., Donovan, J., Windish, R., Steining, C., Mahyuddin, P., Womack, J. E., and Lewin, H. A. 2000. "An Ordered Comparative Map of the Cattle and Human Genomes." Genome Res. 10 (9): 1359-68.

[6] Khatib, H., Huang, W., Mikheil, D., Schutzkus, V., and Monson, R. L. 2009. "Effects of Signal Transducer and Activator of Transcription (STAT) Genes STAT1 and STAT3 Genotypic Combinations on Fertilization and Embryonic Survival Rates in Holstein Cattle.” J. Dairy Sci. 92 (12): 6186-91.

[7] Mosig, M. O., Lipkin, E., Khutoreskaya, G., Tchourzyna, E., Soller, M., and Friedmann, A. 2001. "A Whole Genome Scan for Quantitative Trait Loci Affecting Milk Protein Percentage in Israeli-Holstein Cattle, by Means of Selective Milk DNA Pooling in a Daughter Design, Using an Adjusted False Discovery Rate Criterion." Genetics 157 (4): 1683-98.

[8] Ashwell, M. S., Heyen, D. W., Sonstegard, T. S., Van Tassell, C. P., Da, Y., Van Raden, P. M., Ron, M., Weller, J. I., and Lewin, H. A. 2004. "Detection of Quantitative Trait Loci Affecting Milk Production, Health and Reproductive Traits in Holstein Cattle.” J. Dairy Sci. 87 (2): 468-75.

[9] Sambrook, J., and Russel, D. W. 2001. Molecular Cloning: A Laboratory Manual. Vol. 3. New York, USA: Cold Spring Harboc Lab. Press, 999.

[10] Cobanoglu, O., Zaitoun, I., Chang, Y. M., Shook, G. E., and Khatib, H. 2006. "Effects of the Signal Transducer and Activator of Transcription-1 (STAT1) Gene on Milk Production Traits in Holstein Dairy Cattle.” J. Dairy Sci. 89 (11): 4433-7.

[11] SPSS Statistics Inc.. 2004. SPSS 13.0 Base User's Guide. Chicago, IL: IBM SPSS Inc..

[12] Mao, J., Molenaar, A. J., Wheeler, T. T., and Seyfert, H. M. 2002. "STAT5 Binding Contributes to Lactational Stimulation of Promoter III Expressing the Bovine Acetyl-CoA Carboxylase $\alpha$-Encoding Gene in the Mammary Gland.” J. Mol. Endocrinol.29 (1): 73-88.

[13] Chu, M., and Zan, L. S. 2009. "Association between Polymorphism of STAT1 Gene and Milk Production Traits in Chinese Holstein Cattle." Acta Veterinaria et Zootechnica Sinica 40 (3): 309-14.

[14] Askari, G. H., Mahyari, S. A., Mianji, G. R., and Nanaei, H. A. 2013. "Effect of STAT1 Variants on Milk Production Traits in Esfahan Holstein Cows." Int. J. Adv. Biol. Biomed. Res. 1 (8): 851-7.

[15] Rychtarova, J., Sztankoova, Z., Kyselova, J., Zink, V., Stipkova, M., Vacek, M., and Stolc, L. 2014. "Effect of DGAT1, BTN1A1, OLR1 and STAT1 Genes on Milk 
Turkish Holstein and Jersey Cows

Production and Reproduction Traits in the Czech Fleckvieh Breed.” Czech. J. Anim. Sci. 59 (2): 45-53.

[16] Kumar, M., Vohra, V., Ratwan, P., and Chakravarty, A. K. 2015. "Exploring Polymorphism in 3'UTR Region of STAT1 Gene in Different Buffalo Breeds." Indian J.
Dairy Sci. 68 (5): 473-6.

[17] Deng, T. X., Pang, C. Y., Lu, X. R., Zhu, P., Duan, A. Q., and Liang, X. W. 2016. "Associations between Polymorphisms of the STAT1 Gene and Milk Production Traits in Water Buffaloes.” J. Anim. Sci. 94 (3): 927-35. 